\title{
Functional Lactide Monomers: Methodology and Polymerization
}

\author{
Warren W. Gerhardt ${ }^{1}$, David E. Noga ${ }^{1}$, Kenneth I. Hardcastle ${ }^{3}$, Andrés J. García ${ }^{2}$, David M. \\ Collard $^{1, *}$, and Marcus Weck ${ }^{1, *}$ \\ 1 School of Chemistry and Biochemistry, Georgia Institute of Technology, Atlanta, Georgia 30332-0400 \\ 2 Woodruff School of Mechanical Engineering and Institute for Bioengineering and Bioscience, Georgia \\ Institute of Technology, Atlanta, Georgia 30332-0400
}

3 X-Ray Crystallographic Center, Department of Chemistry, Emory University, Atlanta, GA 30322

\begin{abstract}
Side-chain functionalized lactide analogues have been synthesized from commercially available amino acids and polymerized using stannous octoate as a catalyst. The synthetic strategy presented allows for the incorporation of any protected amino acid for the preparation of functionalized diastereomerically pure lactide monomers. The resulting functionalized cyclic monomers can be homopolymerized, and copolymerized with lactides, then quantitatively deprotected forming new functional poly(lactide)-based materials. This strategy allows for the introduction of functional groups along a poly(lactide) (PLA) backbone that after deprotection can be viewed as chemical handles for further functionalization of PLA, yielding improved biomaterials for a variety of applications.
\end{abstract}

\section{Introduction}

The prominence and development of biodegradable and renewable polyesters has risen dramatically over the last 30 years. ${ }^{1}$ Poly(lactide) (PLA), a poly(2-hydroxypropionic acid), used in fibers and packaging, ${ }^{2}$ is a versatile biorenewable polymeric material, ${ }^{3}$ which is also both biocompatible and bioresorbable. These traits give PLA an important role as a biomaterial in the medical field with uses in implantation devices, sutures, tissue replacement, and as a delivery vehicle. ${ }^{3-6}$ However, a major shortcoming of PLA is its lack of functional group diversity along the polymer backbone. Pendant functionalities incorporated as side-chains of a PLA would allow for greater control of its material properties such as degradation rate, hydrophilicity, and mechanical strength. ${ }^{7-9}$ Furthermore, it may allow for easy postpolymerization functionalization with a wide variety of biological moieties thereby providing a novel route towards functionalized biomaterials. While a number of these strategies have taken advantage of glycolide and morpholine-2,5-dione analogs, ${ }^{10-17}$ there is a conspicuous absence of functionally diverse lactides. The development of diverse applications for PLAs and the potential to prepare bioconjugate materials based on the lactide backbone has prompted us to develop a general synthetic and polymerization methodology towards a wide range of functional lactides.

Since Kimura's first report on the synthesis of a glycolide-based poly(ester) with pendant carboxylic acids ${ }^{10}$ several groups have expanded on this poly(glycolide) functionalization scheme. ${ }^{11,12}$ A significant simplification in the synthesis of functional glycolides relative to analogous lactides is the presence of only one stereocenter, which precludes the generation of 
diastereomers. While easier to synthesize, poly(glycolide) analogs are more hydrophilic 18 and less crystalline. ${ }^{19}$ Therefore they are often poorly suited for some medical applications due to their generally faster hydrolytic degradation rates in vivo. ${ }^{18,19}$

In an analogous fashion, Feijen has reported on the development of morpholine-2,5-dione derivatives, that are subject to ring-opening polymerizations to give poly(ester-amides), ${ }^{13}$ and several other important reports describing variations of the Feijen strategy have appeared in the literature (Figure 1). ${ }^{14,15}$ Again though, differences in the polymerization behavior of these monomers compared to their lactide analogs is observed due to the presence of the amide groups, which directs the opening of the monomer to the ester thereby retarding the rate of polymerization 20 and effecting the rate of in vivo hydrolysis and enzymatic degradation rates. 19 Therefore the need for a synthetic route towards functionally diverse lactides is evident.

In this contribution, we define a functional lactide as a 6-methyl-1,4-dioxane-2,5-dione framework with a functional group-bearing substituent at the 3 position that is amenable to further derivatization. Previous alterations to the lactide skeleton have mainly involved substitution of the 3-methyl group with other alkyl groups, phenyl, or alkenyl groups; with seminal work reported by Baker $6,16,17$ and Möller. ${ }^{9}$ Both groups have described efficient strategies towards the preparation of alkyl substituted lactides as well as their incorporation into homo- and co-polymers. In addition, there are several interesting reports on extending the substitution strategy from the mono-functionalized monomers to bi-functionalized analogs, 21,22 but there are only two reports in the literature of asymmetric functional lactide monomer analogues containing heteroatomic functionalities, amenable to further post-polymerization functionalization. The first incorporates a protected sugar, gluconic acid. ${ }^{11}$ However, the homopolymerization of this functional lactide resulted in extremely low conversions and degrees of polymerization. The most recent example describes an alternate synthetic route towards cyclic lactide monomer $\mathbf{1}$, but the authors do not report any attempts at the ring-opening polymerization. ${ }^{8}$ While pertinent, the scope of these reports is limited and the synthesis and polymerization of functional lactides remains a challenge for the development of a broadly applicable synthetic scheme towards functional lactides that will provide access to a new class of renewable and biodegradable functional materials. In this contribution, we demonstrate such a synthetic strategy by describing a synthetic pathway towards functional lactides starting from commercially available protected amino acids. It is important to note that any amino acid can be utilized in our modular strategy allowing for the synthesis of a library of functional lactides. Furthermore, we present preliminary homo- and co-polymerization results thereby demonstrating that our new monomers can be polymerized, successfully incorporated into PLA copolymers, and deprotected.

\section{Results and Discussion}

Important to the design of our synthetic strategy is the preservation of the biorenewable character of our functional monomers whereby we make use of commercially available sidechain protected L-amino acids (Figure 2). We rationalized that readily available amino acids provide a large diversity of terminal functional groups in their side-chains and that they are available as single enantiomers. To demonstrate the modular character of our functional PLA synthesis based on amino acids, we present the synthesis of three new functional lactide monomers, 1-3, containing protected amines, carboxylic acids, and alcohols in their sidechains (Figure 2) as well as their homopolymerization and copolymerization.

Our synthetic strategy is based on the simple conversion of amino acids to their corresponding $\alpha$-hydroxy acids. These are then coupled with either $(S)$ 2-bromopropionyl chloride or $(S)$ 2bromopropionic acid and cyclized to provide the monofunctional lactide (Scheme 1). 
Our synthetic strategy commences with the diazotization of the amino acid to the corresponding $\alpha$-hydroxy acid, with full retention of the stereochemistry. 23,24 The transformation requires sodium nitrite addition to the amino acid in an aqueous acid solution. As reported by others, 23 the yields of the diazotization vary widely based on the rate of sodium nitrite addition, choice of acid, and the reaction temperature. The yields shown in Schemes 1 and 2 range from $60 \%$ for 5 to $72 \%$ for $\mathbf{6}$. Since 2-bromopropionyl chloride is only commercially available in the racemic form, we synthesized (S) 2-bromopropionyl chloride from L-alanine by diazotization in $\mathrm{HBr}$ to provide $(S)$ 2-bromopropionic acid, followed by the conversion to the acid chloride with thionyl chloride. ${ }^{20}$ The conditions for the cyclization of each functionalized $\alpha$-hydroxy acid with lactic acid to provide the functional cyclic diester varied depending on the lability of each protecting group (Schemes 1 and 2).

The robustness of the benzyl ether protecting group made the synthesis of monomer $\mathbf{1}$ the most convenient with limited side-reactions throughout the synthetic pathway. Ester 7 was synthesized by treating $\alpha$-hydroxy-acid 4 with $(S)$ 2-bromopropionyl chloride. Racemization of the enolizable acid chloride $\alpha$-proton in these acidic conditions was expected, and the diastereomeric mixture subjected to halide exchange by a Finkelstein reaction followed by cyclization without separation. The synthesis of $\mathbf{8}$, with an acid labile urethane linkage, required the use of lower temperatures and the addition of $N, N$-diisopropylethylamine (DIEA) to scavenge the $\mathrm{HCl}$. However, these conditions were still sufficiently harsh generating persistent byproducts, which were spectroscopically and functionally quite similar to $\mathbf{8}$, and therefore difficult to remove. Because the final step is an intramolecular reaction, these unidentified byproducts posed no threat during the cyclization, and the crude monomer precursor was subjected to halide exchange and cyclized, but only low yields of product were obtained. We therefore chose to develop an alternative synthesis of monomer $\mathbf{2}$ that was also successfully employed for monomer $\mathbf{3}$.

Monomers 2 and $\mathbf{3}$ were prepared by the condensation of functionalized $\alpha$-hydroxy acids with (S) 2-bromopropionic acid using dicyclohexylcarbodiimide (DCC) and 1-

hydroxybenzotriazole (HOBt) to provide $\mathbf{8}$ and $\mathbf{9}$. This method circumvented racemization at the new stereocenter through: 1) milder conditions and 2) coupling of an acid instead of the more readily enolizable acid chloride. These couplings were again followed by a halogen exchange and then cyclization, as outlined in Scheme 2.

The main advantage of the coupling step of $\alpha$-hydroxy acids 5 or $\mathbf{6}$ with $(S)$ 2-bromopropionic acid is that the yields of the final cyclization are higher due to a clean conversion to the cyclic monomer precursors 8 and 9 versus monomer precursors of 7 and $\mathbf{8}$ (with persistent byproducts) generated from the acid chloride coupling method of Scheme 1.

Cyclizations of the functional monomer precursors were carried out by slowly adding uncyclized $\alpha$-iodocarboxylic acids 10-12 to a dilute solution of DIEA in acetone. Linear oligomers, the primary side-products of this procedure, were easily removed by filtration of a solution of the crude product through a short plug of silica. The cyclization yield of monomer 1 was $43 \%$ with an overall yield 30\%. Diastereomers of 1 from the acid chloride method were separated by column chromatography (we found that premium grade silica gel led to significantly higher recovery of product compared to standard grade, which led to decomposition of the cyclized monomers), followed by fractional crystallization from EtOAc/ hexanes. The configuration of the stereocenters of the crystalline diastereomer of $\mathbf{1}$ was shown to be $(\mathrm{S}, \mathrm{S})$ as determined by X-ray structural analysis (Figure 3 ). The absolute configuration of cyclic monomer 1 was determined knowing that the stereocenter of the $\alpha$-hydroxy acid half of the molecule retains the $(\mathrm{S})$ configuration of the protected amino acid precursor under the diazotization conditions. 
As mentioned earlier the DCC/HOBt method eliminated the problem of racemization during the preparation of $\mathbf{8}$ and $\mathbf{9}$ thereby allowing for the cyclization to $\mathbf{2}$ and $\mathbf{3}$ with a $>95 \%$ diastereomeric excess (as shown by ${ }^{1} \mathrm{H}-\mathrm{NMR}$ ), in yields unprecedented for the cyclization step of any cyclic lactide analogue. These single diastereomers were purified by column chromatography on silica gel, $\mathbf{3}$ was isolated with a $73 \%$ yield as an oil, overall yield of $48 \%$. Monomer 2 was recrystallized and isolated with a $75 \%$ yield, overall yield of $42 \%$, as a white crystalline solid. With the configuration of the stereocenter of monomer $\mathbf{2}$ contributed from the protected amino acid half known to be (S), the absolute configuration of the stereocenters of $\mathbf{2}$ was also shown to be (S,S) as determined by X-ray structural analysis (Figure 4).

It is important to note that our new synthetic methodology allows for the retention of the stereochemistry throughout the synthesis of the functional lactides. The properties of poly (lactide)s depends strongly on the tacticity of the final polymers. ${ }^{2}$ Over the past decade, a variety of groups have developed metal catalysts that allow for the control of the tacticity during the polymerization with the appropriate lactide stereoisomer(s). ${ }^{25,} 26$ Therefore, while the scope of this study was not to investigate the stereoregular polymerization of our monomers using these catalysts, our synthetic methodology allows for the generation or separation of diastereomers that can then be employed in a stereoregular homo- or co-polymerization using these metal catalysts. This allows for complete control over polymer tacticity and thereby the properties of the resulting material.

To determine if our functionalized monomers could be polymerized, preliminary homo- and co-polymerizations were performed. For this study we restricted our investigation to the use of stannous octoate $\left(\mathrm{SnOct}_{2}\right)$ as the catalyst. $\mathrm{SnOct}_{2}$ has been approved by the FDA as an indirect food additive $3,19,27$ and is among the most active and widely used catalyst for the polymerization of lactides and related monomers. ${ }^{22}$

All polymerizations were carried out in bulk. The monomers and catalyst were added to the reaction vessels in a nitrogen-filled glove box, along with a solubilizing amount of dry benzene (triply distilled). The reaction vessels were removed from the glove box, the solutions frozen, lyophilized and dried overnight. They were then heated to $140{ }^{\circ} \mathrm{C}$ under an atmosphere argon starting the polymerization. Consumption of all monomers occurred within 24 hours for the homopolymers $\left({ }^{1} \mathrm{H}\right.$ NMR). For the copolymers conversion plateaued at eight hours, with stirring ceasing for CP1 and CP2 after 3-5 hours (Scheme 3). Longer polymerization times (48 hours) and lower catalyst ratios $(0.1 \%)$ did not yield higher molecular weight polymers; these same polymerization conditions gave poly(DL lactide) with a $M_{\mathrm{n}}$ of 65,000. Upon cooling, the polymers were purified by precipitation from $\mathrm{CH}_{2} \mathrm{Cl}_{2}$ into cold methanol (icewater bath). Yields were based on the mass of each polymer isolated after precipitations. All polymers were characterized by ${ }^{1} \mathrm{H}$ NMR, ${ }^{13} \mathrm{C}$ NMR, GPC, and DSC (homopolymers Table 1; copolymers Table 2).

Proton NMR showed broad signals characteristic of a polymer, and gel-permeation chromatography (GPC) confirmed the conversion to high molecular weight polymers for homopolymer P1 and copolymers $\mathbf{C P 1}{ }^{28}$ and $\mathbf{C P 2}$. The lower molecular weights of all of these monomers versus lactide is not unexpected owing to the steric bulk of the side-chains, which is known to decrease the $\Delta G$ of the polymerization. ${ }^{29}$ However, the low molecular weight of copolymer CP3 may indicate that the side-chain of monomer $\mathbf{3}$ has other interactions with the catalyst retarding the polymerization of itself and the lactide component. All of these results are also in agreement with prior reports of the polymerization of other lactide analogs 16 and substituted morpholine-2,5-dione, ${ }^{20}$ and the very low molecular weights of all the polymers derived from monomer $\mathbf{3}$ were also observed in analogs that contain similar functionalities. 21 Based on the low molecular weights of most of these polymers, the near quantitative conversion of all monomers as measured by ${ }^{1} \mathrm{H}$ NMR presumably led to low molecular weight 
oligomers owing to low polymerization rates and/or possible trans esterification reactions. 6 However, the incorporation of the functional monomers into their copolymers is in close agreement with the stoichiometric ratio of the monomer:lactide reaction mixtures for $\mathbf{C P 1}$ and CP2. Differential-scanning calorimetry of each polymer showed glass-transition temperatures ranging from 5 to $27^{\circ} \mathrm{C}$, which is below the value for poly(lactide) itself. This can be attributed to the presence of the flexible side-chains, which act as internal plasticizers. ${ }^{16}$

These preliminary polymerization results clearly show the potential of monomers $\mathbf{1}$ and $\mathbf{2}$ as new functional poly(lactide) analogues. The unsatisfactory results obtained for monomer $\mathbf{3}$ may be attributed to retardation of the catalyst by coordination of the benzyl glutamate sidechain. Also, monomer 3 being an oil was harder to purify and dry in contrast to the crystalline monomers, the possible presence of scant amounts of adventitious water, despite rigorous drying procedures, may act as an undesirable initiator limiting molecular weights. Through the screening of an array of catalyst/initiator we are optimistic that higher molecular weights can be obtained for monomers $\mathbf{1}$ and $\mathbf{2}$.

Deprotection of homo- and co-polymers $\mathbf{P 1}$ and CP1 derived from serine, and homo- and copolymers P3 and CP3 derived from glutamic acid was accomplished by hydrogenolysis using $\mathrm{Pd}(\mathrm{OH})_{2}$ as the hydrogenation catalyst revealing the hydroxyl and carboxylic acid functional groups respectively (Scheme 4A). Clean and quantitative removal of all benzyl ether and ester protecting groups from the homo- and co-polymers was confirmed by the disappearance of the aromatic and benzylic signals from the ${ }^{1} \mathrm{H}$ NMR and ${ }^{13} \mathrm{C}$ NMR spectra. This process did not result in the degradation of the polyester backbone, as shown by the lack of signals between $4.2-4.4 \mathrm{ppm}$ associated with the $\alpha$-hydroxy proton that would be apparent upon the cleavage of the backbone (Figure 5), this was also observed in the ${ }^{1} \mathrm{H}$ NMR spectra of all of the copolymers.

However, homo- and co-polymers $\mathbf{P 2}$ and $\mathbf{C P 2}$ were recalcitrant towards hydrogenolysis and were deprotected using $\mathrm{HBr}(33 \%) / \mathrm{AcOH}$ for two hours (Scheme 4B).

Clean and quantitative removal of the benzyl carbamate without backbone degradation was again confirmed by ${ }^{1} \mathrm{H}$ NMR and ${ }^{13} \mathrm{C}$ NMR, by observing the disappearance of the aromatic and benzylic signals and the absence of a signal in the region of the $\alpha$-hydroxy proton in the ${ }^{1} \mathrm{H}$ NMR spectrum (Figure 6). Unfortunately, the newly revealed functional groups of all but one of the new homopolymers precluded their characterization by GPC owing to solubility problems of the deprotected homopolymers in $\mathrm{CH}_{2} \mathrm{Cl}_{2}$ and the different hydrodynamic volumes of the deprotected copolymers. GPC analysis of the deprotected copolymer CP1a showed a decrease in molecular weight of approximately $35 \%$ corresponding to full cleavage of the benzyl protecting group and no cleavage of the polymer backbone. Also the GPC trace of poly(DL lactide) with a $M_{\mathrm{n}}$ of 30,000 had the same $M_{\mathrm{n}}$ and peak shape before and after being exposed to each of the deprotection conditions.

\section{Conclusion}

In conclusion, we have developed a modular strategy towards the synthesis and polymerization of functional lactides from commercially available protected amino acids. To demonstrate this new strategy, we have synthesized three new functional lactide monomers containing protected amine, alcohol, and carboxylic acid functionalities, we then investigated the homopolymerization behavior using the metal catalyst stannous octoate and then successfully copolymerized each monomer with lactide. Removal of the protecting groups from every polymer was quantitative with no scission of the backbone observed. Monomers $\mathbf{1}$ and $\mathbf{2}$ had the most promising polymerization results, upon deprotection; these new polymers yielded highly functional, biorenewable materials with a multitude of potential applications in the 
medical field. Optimization of the polymerizations for monomers $\mathbf{1}$ and $\mathbf{2}$ will be further investigated, specifically looking at an array of catalysts/initiators. Future work will focus on the development of strategies for post-polymerization modification and decomposition studies of these new functional materials.

\section{Experimental Section}

\section{Materials and Methods}

H-Ser (Benzyl)-OH was purchased from Indofine Chemical Company. H-Glu(O-Benzyl)-OH was purchased from 3B Medical Systems. H-Lys(Z)-OH was purchased from Fluka. DL lactide was purchased form Aldrich and recrystallized ( $2 x)$ from dry EtOAc, dissolved in dry benzene, frozen, lyophilized and stored in a nitrogen filled glove box prior to use. N,N-Diisopropylethyl amine (DIEA), $\mathrm{Et}_{2} \mathrm{O}$ and benzene were distilled from sodium benzophenone ketyl solutions, EtOAc from $\mathrm{CaH}_{2}$, acetone from $4 \AA$ molecular sieves, and $\mathrm{CH}_{2} \mathrm{Cl}_{2}$ was dried via passage through $\mathrm{Cu}_{2} \mathrm{O}$ and alumina columns. All anhydrous liquids brought into the nitrogen-filled glove box were first degassed with three freeze-pump-thaw cycles using liquid nitrogen at 50 mmHg. Chromatography was performed with Sorbent Tech Premium Grade silica: porosity $60 \AA$, particle size $40-75 \mu \mathrm{m}(200 \times 400 \mathrm{mesh})$, surface area $450-550 \mathrm{~m}^{2} / \mathrm{g}$, pH range 6-8., decomposition of cyclic monomer 1 was observed during chromatography using Sorbent Tech Standard Grade silica: porosity $60 \AA$, particle size 32-63 $\mu \mathrm{m}$ (230_450 mesh), surface area $500-600 \mathrm{~m}^{2} / \mathrm{g}$, pH range $6.5-7.5$. Compounds were analyzed by use of UV light $(254 \mathrm{~nm})$, $\mathrm{I}_{2}$, or a $5 \%$ solution of ammonium molybdate in $2 \mathrm{M}$ sulfuric acid. IR spectra were recorded on a Schimadzu FT-IR-8400S. Melting points were determined with a Mel-Temp II apparatus fitted with a Fluke $51^{\mathrm{K} / \mathrm{J}}$ digital thermometer and are uncorrected. Molecular weight data were collected on a Schimadzu GPC system consisting of a SCL-10Avp system controller, an LC-10ADvp pump, and a SPD-M10Avp diode array detector. The eluant was methylene chloride, and the columns were American Polymer Standards Corp. AM GPC Gel $10 \mu \mathrm{m}$. The molecular weights were determined relative to narrow molecular weight (polydispersity index $\leq 1.05$ ) poly(styrene) standards from American Polymer Standards Corp. Thermal transition data were collected with a Mettler DSC $822^{\mathrm{e}}$. The sample size ranged from $6-8 \mathrm{mg}$, and each sample was subjected to two cool-heat-cool cycles from 25 to -50 to $60{ }^{\circ} \mathrm{C}$ with a rate of 10 ${ }^{\circ} \mathrm{C} / \mathrm{min}$. NMR spectra were recorded at $298 \mathrm{~K}$ on a Varian Mercury spectrometer $(300 \mathrm{MHz})$. Chemical shifts are reported in parts per million (ppm), using residual solvent as an internal standard. Mass spectral analyses were provided by the Georgia Institute of Technology Mass Spectrometry Facility. Elemental analyses were conducted at Atlantic Microlab, Inc. in Norcross, GA.

3-Benzyloxy-2-hydroxypropionic acid (4)—H-Ser(benzyl)-OH (20.0 g, $102.5 \mathrm{mmol}$ ) was dissolved in aq. TFA $(0.7 \mathrm{M}, 200 \mathrm{~mL})$ and $\mathrm{NaNO}_{2}(10.6 \mathrm{~g}, 153.7 \mathrm{mmol})$ in deionized water $(100 \mathrm{~mL})$ was added over a period of three hours using a syringe pump at $25^{\circ} \mathrm{C}$. The reaction mixture was stirred for an additional three hours at $25^{\circ} \mathrm{C}$. $\mathrm{NaCl}(20.0 \mathrm{~g})$ was added to the reaction mixture and the crude product was extracted several times with EtOAc. The combined organic layers were washed with brine, dried over $\mathrm{MgSO}_{4}$, the solvent removed under reduced pressure, and dried in vacuo yielding a yellow oil. The product was further purified by flash column chromatography (silica gel, eluant: 97:2:1 $\mathrm{CH}_{2} \mathrm{Cl}_{2}: \mathrm{MeOH}: \mathrm{AcOH}$ ) and the product was dried in vacuo to give a waxy pale yellow solid $(15.2 \mathrm{~g}, 76 \%) .{ }^{1} \mathrm{H}$ NMR $\left(300 \mathrm{MHz}, \mathrm{CDCl}_{3}\right) \delta: 7.25-7.35(\mathrm{~m}, 5 \mathrm{H}), 4.5(\mathrm{~s}, 1 \mathrm{H}), 4.3(\mathrm{t}, J=3.7,1 \mathrm{H}), 3.7-3.8(\mathrm{~m}$, $2 \mathrm{H}) ;{ }^{13} \mathrm{C}$ NMR $\left(300 \mathrm{MHz}, \mathrm{CDCl}_{3}\right) \delta: 173.4,138.8,128.4,127.7,127.6,73.1,72.3,70.8$; IR (thin film) v: 3400, 3028, 2918, 2864, 1716, 1203, 1095, 735, $696 \mathrm{~cm}^{-1}$; MS (EI) m/z (relative intensity): $196.1\left(\mathrm{M}^{+}, 29\right), 107.1$ (32), 91.1 (100); HRMS (EI) calcd for $\mathrm{C}_{10} \mathrm{H}_{12} \mathrm{O}_{4}$ : 196.07356, found: 196.07363 . 
6-(Benzyloxycarbonylamino)-2-hydroxyhexanoic acid (5)-A $1 \mathrm{M}$ solution of aq. $\mathrm{KHSO}_{4} / \mathrm{CH}_{3} \mathrm{CN}$ was prepared by dissolving $\mathrm{KHSO}_{4}(136.0 \mathrm{~g}, 1 \mathrm{~mole})$ in deionized water (700 $\mathrm{mL})$ and adding $\mathrm{CH}_{3} \mathrm{CN}(300 \mathrm{~mL})$. H-Lys $(\mathrm{Z})-\mathrm{OH}(10.0 \mathrm{~g}, 35.7 \mathrm{mmol})$ was dissolved in the solution and it was then cooled to $0{ }^{\circ} \mathrm{C}$ and an aqueous solution $(100 \mathrm{~mL})$ of $\mathrm{NaNO}_{2}(37.0 \mathrm{~g}$, $535.7 \mathrm{mmol}$ ) was added over a period $20 \mathrm{~min}$ using a syringe pump. The reaction mixture was kept at $0{ }^{\circ} \mathrm{C}$ and stirred for an additional three hours. $\mathrm{NaCl}(20.0 \mathrm{~g})$ was added to the reaction mixture and the crude product was extracted several times with EtOAc. The combined organic layers were washed with water and brine and dried over $\mathrm{MgSO}_{4}$. The solvent was removed under reduced pressure and the residue dried in vacuo to give a waxy yellow solid. The product was further purified by flash column chromatography (silica gel, eluant: 97:2:1

$\left.\mathrm{CH}_{2} \mathrm{Cl}_{2}: \mathrm{MeOH}: \mathrm{AcOH}\right)$ and the product was dried in vacuo to give a pale yellow solid $(6.0 \mathrm{~g}$, $60 \%) .{ }^{1} \mathrm{H}$ NMR $\left(300 \mathrm{MHz}, \mathrm{CDCl}_{3}\right) \delta: 7.30-7.50(\mathrm{~m}, 5 \mathrm{H}), 5.5(\mathrm{~s}, 2 \mathrm{H}), 4.2(\mathrm{dd}, J=4.2,7.5,1 \mathrm{H})$, $3.7(\mathrm{~m}, 2 \mathrm{H}), 1.85-1.75(\mathrm{~m}, 1 \mathrm{H}), 1.70-1.60(\mathrm{~m}, 1 \mathrm{H}), 1.55-1.30(\mathrm{~m}, 4 \mathrm{H}) ;{ }^{13} \mathrm{C}$ NMR $(300 \mathrm{MHz}$, $\mathrm{CDCl}_{3}$ ) $\delta: 178.1,154.0,132.1,128.8,128.7,128.5,69.9,69.8,40.3,33.7,26.2,22.1$; IR (thin film) v: 3345, 2948, 2936, 1731, 1690, 1609, 1583, 1544, 1272, 748, $731 \mathrm{~cm}^{-1}$; MS (ES ${ }^{+}$): $282.2(\mathrm{M}+1)$.

2-Hydroxypentanedioic acid 5-benzyl ester (6)-H-Glu(O-Benzyl)-OH (15.0 g, 63.3 $\mathrm{mmol})$ was dissolved in a solution of 1:1 deionized water:acetic acid $(350 \mathrm{~mL})$ and cooled to $0{ }^{\circ} \mathrm{C} . \mathrm{NaNO}_{2}(34.5 \mathrm{~g}, 500 \mathrm{mmol})$ in deionized water $(50 \mathrm{~mL})$ was added over $20 \mathrm{~min}$ via a syringe pump and stirred for one hour at $0{ }^{\circ} \mathrm{C}$. The reaction was allowed to warm up to $25^{\circ} \mathrm{C}$ and was stirred for an additional two hours. The crude product was extracted several times with EtOAc. The combined organic layers were washed with water and brine, and dried over $\mathrm{MgSO}_{4}$. The solvent was removed under reduced pressure and dried in vacuo to give a light brown oil $(10.9 \mathrm{~g}, 72 \%) .{ }^{1} \mathrm{H}$ NMR $\left(300 \mathrm{MHz}, \mathrm{CDCl}_{3}\right) \delta: 7.3(\mathrm{~m}, 5 \mathrm{H}), 5.1(\mathrm{~s}, 2 \mathrm{H}), 4.3(\mathrm{dd}, J=$ $4.1,3.8,1 \mathrm{H}), 2.55(\mathrm{~m}, 2 \mathrm{H}), 2.2(\mathrm{~m}, 1 \mathrm{H}), 2.0(\mathrm{~m}, 1 \mathrm{H}) ;{ }^{13} \mathrm{C} \mathrm{NMR}\left(300 \mathrm{MHz}, \mathrm{CDCl}_{3}\right) \delta: 177.9$, 173.5, 135.3, 128.4, 128.2, 128.1, 69.4, 66.7, 29.9, 28.9; IR (thin film) v: 3439, 3034, 2945, $1728,1713,1259,1211,1170,1103,739,698 \mathrm{~cm}^{-1}$; MS (EI) $\mathrm{m} / \mathrm{z}$ (relative intensity): 238.1 $\left(\mathrm{M}^{+}, 8\right), 210.1$ (28), 108.1 (88), 107 (65), 91.1 (54), 85 (100), 79 (64), 51 (14); HRMS (EI) calcd for $\mathrm{C}_{12} \mathrm{H}_{14} \mathrm{O}_{5}: 238.08412$, found: 238.08146 .

\section{3-(Benzyloxy)-2-(2-bromopropanoyloxy)propanoic acid (7)-(S) 2-}

Bromopropionyl chloride $(6.3 \mathrm{~mL}, 61.2 \mathrm{mmol})$ was added to $4(10.0 \mathrm{~g}, 51 \mathrm{mmol})$ and the mixture was heated at $70{ }^{\circ} \mathrm{C}$ under an argon atmosphere in a three-neck round bottom flask equipped with a $\mathrm{NaOH}$ trap. Once the reaction was completed as shown by thin-layer chromatography (TLC) (approx. six hours), the dark brown oil was placed in a Kugelrohr and distilled at $60{ }^{\circ} \mathrm{C}$ and $50 \mathrm{mmHg}$ overnight to remove excess 2-bromopropionic acid. Crude 7 was further purified by flash column chromatography (silica gel, eluant: 98:1.5:0.5

$\mathrm{CH}_{2} \mathrm{Cl}_{2}: \mathrm{MeOH}$ :AcOH). The solvent was removed in vacuo to give a brown oil in $94 \%$ yield. Compound 7 was carried on to the halogen exchange step without further purification.

6-Benzyloxycarbonylamino-2-(2-bromopropionyloxy)hexanoic acid (8)-(S) 2Bromopropionic acid $(0.242 \mathrm{~mL}, 2.7 \mathrm{mmol})$ and 1-hydroxybenzotriazole (HOBt) $(0.32 \mathrm{~g}, 2.4$ mmol) were dissolved in dry $\mathrm{CH}_{2} \mathrm{Cl}_{2}(10 \mathrm{~mL})$. Once homogeneous, the solution was cooled to $0{ }^{\circ} \mathrm{C}$ and dicyclohexylcarbodiimide (DCC) $(0.42 \mathrm{~g}, 2.0 \mathrm{mmol})$ was added in one portion. The reaction was stirred in an ice bath for $5 \mathrm{~min}$ and then stirred for an additional $20 \mathrm{~min}$ at 25 ${ }^{\circ} \mathrm{C}$. Dicyclohexylurea (DCU) started to precipitate out instantly upon DCC addition. After a 25 min incubation period, a solution of $5(0.37 \mathrm{~g}, 1.3 \mathrm{mmol})$ in $\mathrm{CH}_{2} \mathrm{Cl}_{2}(15 \mathrm{~mL})$ was added dropwise over $20 \mathrm{~min}$ via an addition funnel. The reaction mixture was stirred for twelve hours becoming a dark brown color. It was then filtered through celite to remove DCU. The solvent was removed under reduced pressure and the brown oil redissolved in EtOAc and cooled in a freezer to precipitate out the unreacted DCC which was then filtered off through celite, and 
washed several times with water to remove most of the HOBt. The solvent was removed under reduced pressure and the dark brown oil was placed in a Kugelrohr and distilled at $60{ }^{\circ} \mathrm{C}$ and $50 \mathrm{mmHg}$ overnight to remove excess 2-bromopropionic acid. Crude $\mathbf{8}$ was further purified by flash column chromatography (silica gel, eluant: 98:1.5:0.5 $\mathrm{CH}_{2} \mathrm{Cl}_{2}: \mathrm{MeOH}: \mathrm{AcOH}$ ). The solvent was removed under reduced pressure and the residue dried in vacuo to give a dark brown oil $(0.51 \mathrm{~g}, 93 \%)$. Compound $\mathbf{8}$ was carried on to the halogen exchange step without further purification.

2-(2-Bromo-propionyloxy)pentanedioic acid 5-benzyl ester (9)-(S) 2-Bromopropionic acid $(0.24 \mathrm{~mL}, 2.7 \mathrm{mmol})$ and 1-hydroxybenzotriazole (HOBt) $(0.32 \mathrm{~g}, 2.4 \mathrm{mmol})$ were dissolved in dry $\mathrm{CH}_{2} \mathrm{Cl}_{2}(10 \mathrm{~mL})$. The solution was cooled to $0{ }^{\circ} \mathrm{C}$ and dicyclohexylcarbodiimide (DCC) $(0.42 \mathrm{~g}, 2.0 \mathrm{mmol})$ was added in one portion. The reaction was stirred in an ice bath for $5 \mathrm{~min}$ and then stirred for an additional $20 \mathrm{~min}$ at $25^{\circ} \mathrm{C}$.

Dicyclohexylurea (DCU) started to precipitate out instantly upon DCC addition. After a 25 min incubation period, a solution of $\mathbf{6}(0.32 \mathrm{~g}, 1.3 \mathrm{mmol})$ in $\mathrm{CH}_{2} \mathrm{Cl}_{2}(15 \mathrm{~mL})$ was added dropwise over $20 \mathrm{~min}$ via an addition funnel. The reaction mixture was stirred for twelve hours becoming a light brown color. It was then filtered through celite to remove the DCU. The solvent was removed under reduced pressure and the brown oil redissolved in EtOAc and cooled in a freezer to precipitate out the unreacted DCC, which was then filtered off through celite, and then washed several times with water to remove most of the HOBt. The solvent was removed under reduced pressure and the dark brown oil was placed in a Kugelrohr and distilled at $60^{\circ} \mathrm{C}$ and $50 \mathrm{mmHg}$ overnight to remove excess 2-bromopropionic acid. Crude 9 was further purified by flash column chromatography (silica gel, eluant: 98:1.5:0.5

$\left.\mathrm{CH}_{2} \mathrm{Cl}_{2}: \mathrm{MeOH}: \mathrm{AcOH}\right)$. The solvent was removed under reduced pressure and the residue dried in vacuo to give a brown oil $(0.46 \mathrm{~g}, 91 \%)$. Compound 9 was carried on to the halogen exchange step without further purification.

General procedure for the halide exchange-A solution of the $\alpha$-bromocarboxylic acid (7-9) in dry acetone $(100 \mathrm{~mL}$ ) was heated to reflux with a large excess of KI (approx. 10 equivalents) under an argon atmosphere. After twelve hours (quantitative conversion by TLC) the reaction mixture was filtered through celite and the solvent was removed under reduced pressure. The residual dark red oil was redissolved in EtOAc and washed several times with a $2 \mathrm{M}$ aq. $\mathrm{Na}_{2} \mathrm{~S}_{2} \mathrm{O}_{3}$ solution. After the first wash, the dark red color changed to a pale yellow. The organic layer was dried over $\mathrm{MgSO}_{4}$, the solvent was removed under reduced pressure, and the residue was dried in vacuo. The $\alpha$-iodocarboxylic acids (10-12) were used without further purification.

3-(Benzyloxymethyl)-6-methyl-1,4-dioxane-2,5-dione (1)—A solution of $\mathbf{1 0}$ (5.2 g, $13.9 \mathrm{mmol})$ in dry $\mathrm{CH}_{2} \mathrm{Cl}_{2}(100 \mathrm{~mL})$ was added slowly over a period of eight hours to a refluxing solution of DIEA $(4.6 \mathrm{~mL}, 27.7 \mathrm{mmol})$ in dry acetone $(1 \mathrm{~L})$ via a syringe pump. After the complete addition of $\mathbf{1 0}$ the reaction was stirred for an additional hour at reflux and the solvent was removed under reduced pressure. $\mathrm{Et}_{2} \mathrm{O}(100 \mathrm{~mL})$ was added to the light brown oil to precipitate out ammonium iodide, which was filtered off through celite and the solvent was removed under reduced pressure. The linear oligomers were removed by passage through a short column of premium grade silica gel ( $3: 1 \mathrm{v} / \mathrm{v}$ hexanes:EtOAc) to give the crude diastereomeric mixture as a pale brown oil $(1.5 \mathrm{~g}, 43 \%)$. The diastereomers were separated by flash column chromatography (premium grade silica gel, eluant: 80:20 hexanes:EtOAc). The first diastereomer to elute was isolated as a pale brown oil ( $0.53 \mathrm{~g}, 36 \%$ of mixture). ${ }^{1} \mathrm{H}$ NMR $\left(300 \mathrm{MHz}, \mathrm{CDCl}_{3}\right) \delta: 7.2-7.4(\mathrm{~m}, 5 \mathrm{H}), 5.2(\mathrm{q}, J=7.0 \mathrm{~Hz}, 1 \mathrm{H}), 5.0(\mathrm{dd}, J=2.1,2.5 \mathrm{~Hz}, 1 \mathrm{H})$, 4.5 (s, 2H), 4.0 (dd, $J=2.0,10.5 \mathrm{~Hz}, 1 \mathrm{H}), 3.9(\mathrm{dd}, J=2.6,10.5 \mathrm{~Hz}, 1 \mathrm{H}), 1.6(\mathrm{~d}, J=7.0 \mathrm{~Hz}$, $3 \mathrm{H}$ ). The second diastereomer was recrystallized from $\mathrm{Et}_{2} \mathrm{O}$ to give a white crystalline solid (0.93 g, 64\% of mixture). ${ }^{1} \mathrm{H}$ NMR (300 MHz, $\left.\mathrm{CDCl}_{3}\right)$ 8: 7.2-7.1 (m, 5H), 5.07 (t, $J=3.4 \mathrm{~Hz}$, 
$1 \mathrm{H}), 5.0(\mathrm{q}, J=6.9 \mathrm{~Hz}, 1 \mathrm{H}), 4.6(\mathrm{~s}, 2 \mathrm{H}), 4.0(\mathrm{~d}, J=3.5 \mathrm{~Hz}, 2 \mathrm{H}), 1.6(\mathrm{~d}, J=6.9 \mathrm{~Hz}, 3 \mathrm{H}) ;{ }^{13} \mathrm{C}$ NMR (300 MHz, $\left.\mathrm{CDCl}_{3}\right) \delta:$ 166.0, 164.1, 136.4, 128.4, 128.1, 127.9, 76.0, 74.0, 73.1, 68.6, 17.8; IR (thin film) v: 3032, 1770, 1749, 1250, $1093 \mathrm{~cm}^{-1}$; MS (EI) $\mathrm{m} / \mathrm{z}$ (relative intensity): $250.1\left(\mathrm{M}^{+}, 12\right), 144$ (34), 107 (36), 91.1 (100), 65.1 (11); HRMS (EI) calcd for $\mathrm{C}_{13} \mathrm{H}_{14} \mathrm{O}_{5}$ : 250.08384, found: 250.08412; Elemental analysis: calcd for $\mathrm{C}_{13} \mathrm{H}_{14} \mathrm{O}_{5}: \mathrm{C}, 62.39 ; \mathrm{H}, 5.64 ; \mathrm{O}$, 31.97; found: C, 62.36; H, 5.75; O, 32.00; M.P. $85.4-89.8^{\circ} \mathrm{C}$.

Benzyl 4-(5-methyl-3,6-dioxo-1,4-dioxan-2-yl)butylcarbamate (2)—A solution of $11(5.8 \mathrm{~g}, 12.5 \mathrm{mmol})$ in dry $\mathrm{CH}_{2} \mathrm{Cl}_{2}(100 \mathrm{~mL})$ was added slowly over a period of eight hours to a refluxing solution of DIEA $(4.1 \mathrm{~mL}, 24.9 \mathrm{mmol})$ in dry acetone $(1 \mathrm{~L})$ via a syringe pump. After the complete addition of 11, the reaction was stirred for an additional hour at reflux and the solvent was removed under reduced pressure. $\mathrm{Et}_{2} \mathrm{O}(100 \mathrm{~mL})$ was added to the light brown oil to precipitate out ammonium iodide, which was filtered off through celite and the solvent was removed under reduced pressure. The crude product was purified by flash column chromatography (premium grade silica gel, eluant: 80:20 hexanes:EtOAc) to give a clear oil which was recrystallized from EtOAc/hexanes to give a white crystalline solid (3.19 g, 75\%). ${ }^{1} \mathrm{H} \mathrm{NMR}\left(300 \mathrm{MHz}, \mathrm{CDCl}_{3}\right)$ 8: 7.4-7.2 (m, 6H), $5.1(\mathrm{~s}, 2 \mathrm{H}), 4.98(\mathrm{q}, J=5 \mathrm{~Hz}, 1 \mathrm{H}), 4.89$ (dd, $J=4.3,2.8 \mathrm{~Hz}, 1 \mathrm{H}), 4.8$ (br. s, $1 \mathrm{H}), 3.22(\mathrm{q}, J=5.7 \mathrm{~Hz}, 2 \mathrm{H}), 2.1(\mathrm{~m}, 2 \mathrm{H}), 1.95(\mathrm{~m}, 2 \mathrm{H})$, $1.62(\mathrm{~d}, J=6.7 \mathrm{~Hz}, 3 \mathrm{H}), 1.6-1.4$ (br. s, $4 \mathrm{H}) ;{ }^{13} \mathrm{C} \mathrm{NMR}\left(300 \mathrm{MHz}, \mathrm{CDCl}_{3}\right) \delta: 167.2,166.5$, $155.2,136.4,128.4,128.0,127.95,75.5,72.3,66.6,40.6,29.55,29.5,21.5,15.9 ;$ IR (thin film) v: 3331, 2943, 2874, 1782, 1749, 1693, 1688, 1537, 1281, 1265, 1227, $696 \mathrm{~cm}^{-1}$; MS $\left(\mathrm{FAB}^{+}\right) \mathrm{m} / \mathrm{z}$ (relative intensity): $336.1(\mathrm{M}+1,100), 292.1$ (42), 248.1 (12); HRMS (FAB ${ }^{+}$) calcd for $\mathrm{C}_{17} \mathrm{H}_{22} \mathrm{NO}_{6}$ : 336.1447, found: 336.14352 ; Elemental analysis: calcd for $\mathrm{C}_{17} \mathrm{H}_{21} \mathrm{NO}_{6}: \mathrm{C}, 60.89 ; \mathrm{H}, 6.31 ; \mathrm{N}, 4.18$; O, 28.63; found: $\mathrm{C}, 60.87$; H, 6.33; N, 4.16, O, 28.64; M.P. $94.0-98.6^{\circ} \mathrm{C}$.

Benzyl 3-(5-methyl-3,6-dioxo-1,4-dioxan-2-yl)propanoate (3)—A solution of 12 (5.5 $\mathrm{g}, 13.2 \mathrm{mmol})$ in dry $\mathrm{CH}_{2} \mathrm{Cl}_{2}(100 \mathrm{~mL})$ was added slowly over a period of eight hours to a refluxing solution of DIEA $(4.3 \mathrm{~mL}, 26.3 \mathrm{mmol})$ in dry acetone $(1 \mathrm{~L})$ via a syringe pump. After the complete addition of $\mathbf{1 2}$, the reaction was stirred for an additional hour at reflux and the solvent was removed under reduced pressure. $\mathrm{Et}_{2} \mathrm{O}(100 \mathrm{~mL})$ was added to the light brown oil to precipitate out ammonium iodide, which was filtered off through celite and the solvent was removed under reduced pressure. Crude $\mathbf{3}$ was purified by flash column chromatography (silica gel, eluant: 80:20 hexanes:EtOAc) to give a light brown oil (2.8 g, 73\%). ${ }^{1} \mathrm{H}$ NMR (300 MHz, $\left.\mathrm{CDCl}_{3}\right) \delta: 7.34(\mathrm{~m}, 5 \mathrm{H}), 5.12(\mathrm{~s}, 2 \mathrm{H}), 5.09(\mathrm{t}, J=3.8 \mathrm{~Hz}, 1 \mathrm{H}), 4.95(\mathrm{q}, J=6.7 \mathrm{~Hz}, 1 \mathrm{H}), 2.63$ $(\mathrm{q}, 2 \mathrm{H}), 2.48(\mathrm{~m}, 1 \mathrm{H}), 2.21(\mathrm{~m}, 1 \mathrm{H}), 1.64(\mathrm{~d}, J=6.6 \mathrm{~Hz}, 3 \mathrm{H}) ;{ }^{13} \mathrm{C} \mathrm{NMR}\left(300 \mathrm{MHz}, \mathrm{CDCl}_{3}\right)$ $\delta: 171.9,167.0,166.5,135.3,128.31,128.07,127.90,74.0,72.1,66.4,28.3,25.0,15.5$; IR v: (thin film) 3034, 2999, 2947, 1764, 1732, 1246, 1171, 752, $700 \mathrm{~cm}^{-1}$; HRMS $\left(\mathrm{ESI}^{+}\right)$calcd for $\mathrm{C}_{15} \mathrm{H}_{17} \mathrm{O}_{6}$ : 293.106425, found: 293.101965; Elemental analysis: calcd for $\mathrm{C}_{15} \mathrm{H}_{16} \mathrm{O}_{6}$ : C, 61.64; H, 5.52; O, 32.84. found: C, 61.49; H, 5.59; O, 32.92 .

SnOct $_{2}$ Catalyst Stock Solution-In a nitrogen-filled glove box, $\operatorname{SnOct}_{2}(0.32 \mathrm{~g}, 0.8$ $\mathrm{mmol})$ ) was added to a $10 \mathrm{~mL}$ volumetric flask that was then filled to the graduation mark with dry, degassed benzene making a $0.8 \mathrm{M}$ solution, this was transferred to a Schlenk flask and stored inside the glove box.

General Procedure for Homopolymerizations-Crystalline monomers $\mathbf{1}$ and $\mathbf{2}$ were recrystallized (2x) from anhydrous $\mathrm{Et}_{2} \mathrm{O} / \mathrm{EtOAc}$ mixtures and monomer $\mathbf{3}$ was columned repeatedly $(4 \mathrm{x})$ to ensure purity. Each monomer was then frozen in benzene (triply distilled from sodium benzophenone ketyl solutions), lyophilized and stored in a nitrogen filled glove box prior to polymerization. In the nitrogen-filled glove box, the monomer of choice $(0.4$ $\mathrm{mmol}), \operatorname{SnOct}_{2}(2 \mathrm{~mol} \%, 50 \mu \mathrm{L}$ from the stock solution), and a solubilizing amount of benzene 
(approximately $0.75 \mathrm{~mL}$ ) were added to a reaction vessel with a stir bar and sealed with a side arm equipped glass stopper, the flask was removed from the glove box, the mixture was frozen, lyophilized, and dried in vacuo for 24 hours at $25{ }^{\circ} \mathrm{C}$ at $50 \mathrm{mmHg}$ and was heated to $140{ }^{\circ} \mathrm{C}$ while stirring. After 24 hours the mixture was cooled, the crude polymer was dissolved in $\mathrm{CH}_{2} \mathrm{Cl}_{2}$ and precipitated by the dropwise addition of the polymer solution into cold $\mathrm{MeOH}$ at $0{ }^{\circ} \mathrm{C}$, the precipitate was filtered off and dried in vacuo. Molecular weights and polydispersities were determined by gel-permeation chromatography and the glass-transition temperatures were determined by differential-scanning calorimetry.

Homopolymer P1-1 ${ }^{1} \mathrm{H}$ NMR (300 MHz, $\left.\mathrm{CDCl}_{3}\right)$ 8: 7.2-7.4 (s, 5H), 5.1-5.5 (m, 2H), 4.4$4.6(\mathrm{~m}, 2 \mathrm{H}), 3.9-4.0(\mathrm{~m}, 1 \mathrm{H}), 3.7-3.9(\mathrm{~m}, 1 \mathrm{H}), 1.4-1.7(\mathrm{~m}, 3 \mathrm{H}) ;{ }^{13} \mathrm{C}$ NMR $(300 \mathrm{MHz}$, $\left.\mathrm{CDCl}_{3}\right) \delta: 169,166,164,138,129,128,73,72,69,68,67,32,17$.

Homopolymer P2— ${ }^{1} \mathrm{H}$ NMR $\left(300 \mathrm{MHz}, \mathrm{CDCl}_{3}\right)$ \%: 7.2-7.4 (m, 5H), 4.8-5.4 (m, 4H), 3.4$3.6(\mathrm{~m}, 1 \mathrm{H}), 3.0-3.2(\mathrm{~m}, 1 \mathrm{H}), 1.4-2.1(\mathrm{~m}, 9 \mathrm{H})) ;{ }^{13} \mathrm{C} \mathrm{NMR}\left(300 \mathrm{MHz}, \mathrm{CDCl}_{3}\right) \delta: 169,168$, 156, 137, 129, 128, 72, 69, 66, 40, 30, 29, 22, 16.

Homopolymer P3—1 ${ }^{1} \mathrm{H}$ NR $\left(300 \mathrm{MHz}, \mathrm{CDCl}_{3}\right)$ \%: 7.1-7.4 (m, 5H), 4.9-5.3 (m, 4H), 2.12.7 (m, 4H), 1.2-1.6 (m, 3H); ${ }^{13} \mathrm{C}$ NMR (300 MHz, $\left.\mathrm{CDCl}_{3}\right) \delta: 176,172,169,168,136,135$, $129,128,75,72,69,67,66,31,29,27,26,16$.

General Procedure for Copolymerizations-Crystalline monomers 1, 2 were recrystallized (2x) from anhydrous $\mathrm{Et}_{2} \mathrm{O} / \mathrm{EtOAc}$ mixtures, and monomer $\mathbf{3}$ was columned repeatedly $(4 \mathrm{x})$ to ensure purity. Each monomer was then frozen in benzene (triply distilled from sodium benzophenone ketyl solutions), lyophilized and stored in a nitrogen filled glove box prior to polymerization. In the nitrogen-filled glove box, the monomer of choice $(0.2$ $\mathrm{mmol})$, DL lactide (0.087 g, $0.6 \mathrm{mmol})$, SnOct $_{2}(2 \mathrm{~mol} \%, 100 \mu \mathrm{L}$ from the stock solution), and a solubilizing amount of benzene (approximately $0.75 \mathrm{~mL}$ ) were added to a reaction vessel with a stir bar and sealed with a side arm equipped glass stopper, the flask was removed from the glove box, the mixture was frozen, lyophilized, and dried in vacuo for 24 hours at $25^{\circ} \mathrm{C}$ at $50 \mathrm{mmHg}$ and heated to $140{ }^{\circ} \mathrm{C}$ while stirring. After eight hours the reaction was cooled, the crude copolymer was dissolved in $\mathrm{CH}_{2} \mathrm{Cl}_{2}$ and precipitated by the dropwise addition of the polymer solution into cold $\mathrm{MeOH}$ at $0{ }^{\circ} \mathrm{C}$, the precipitate was filtered off and dried in vacuo. Molecular weights and polydispersities were determined by gel-permeation chromatography and the glass-transition temperatures were determined by differential-scanning calorimetry.

Copolymer CP1- ${ }^{1} \mathrm{H}$ NMR (300 MHz, $\left.\mathrm{CDCl}_{3}\right) \delta: 7.2-7.4(\mathrm{~m}, 5 \mathrm{H}), 5.1-5.4(\mathrm{~m}, 7 \mathrm{H}), 4.4-$ $4.60(\mathrm{~m}, 2 \mathrm{H}), 3.8-4.0(\mathrm{~m}, 2 \mathrm{H}), 1.4-1.7(\mathrm{~m}, 18 \mathrm{H}), ;{ }^{13} \mathrm{C} \mathrm{NMR}\left(300 \mathrm{MHz}, \mathrm{CDCl}_{3}\right) \delta: 170,167$, 166, 164, 137, 129, 128, 73, 72, 69, 68, 67, 66, 31, 17.

Copolymer CP2- ${ }^{1} \mathrm{H}$ NMR $\left(300 \mathrm{MHz}, \mathrm{CDCl}_{3}\right) \delta$ : 7.2-7.4 (m, 5H), 4.8-5.3 (m, 18H), 3.4$3.5(\mathrm{~m}, 1 \mathrm{H}), 3.0-3.2(\mathrm{~m}, 2 \mathrm{H}), 1.1-2.1(\mathrm{~m}, 50 \mathrm{H}) ;{ }^{13} \mathrm{C} \mathrm{NMR}\left(300 \mathrm{MHz}, \mathrm{CDCl}_{3}\right) \delta: 170,169$, $168,167,156,137,129,128,78,72,69,66,40,39,30,29,22,20,16$.

Copolymer CP3- ${ }^{1} \mathrm{H}$ NMR $\left(300 \mathrm{MHz}, \mathrm{CDCl}_{3}\right) \delta$ : 7.2-7.4 (m, 5H), 4.9-5.3 (m, 10H), 2.2$2.6(\mathrm{~m}, 4 \mathrm{H}), 1.4-1.8(\mathrm{~m}, 22 \mathrm{H}) ;{ }^{13} \mathrm{C} \mathrm{NMR}\left(300 \mathrm{MHz}, \mathrm{CDCl}_{3}\right) \delta 176,172,170,169,168,167$, 137, 136, 135, 129, 128, 78, 77, 75, 70, 69, 68, 66, 30, 29, 26, 25, 16.

General Procedure for Hydrogenolysis Deprotections-A mixture of polymer, reagent grade EtOAc $(25 \mathrm{~mL})$, and a catalytic amount of wet $20 \% \mathrm{Pd}(\mathrm{OH})_{2}$ on carbon was sealed in a pressure flask on a hydrogenator and charged to $50 \mathrm{PSI}$ with $\mathrm{H}_{2}$ at $25^{\circ} \mathrm{C}$ and agitated 
for four hours. The solution was filtered through celite, the solvent removed under reduced pressure and the product was dried in vacuo.

General Procedure for Acidolysis Deprotections of Benzyl Carbamates-The polymer was dissolved in $33 \% \mathrm{w} / \mathrm{w} \mathrm{HBr}$ in $\mathrm{AcOH}$ under anhydrous conditions and stirred in an inert atmosphere, after two hours the deprotected homopolymers were precipitated by the addition of $\mathrm{Et}_{2} \mathrm{O}$ and dried in vacuo. For the deprotected copolymer $\mathrm{HBr}$ and $\mathrm{AcOH}$ were removed in vacuo. All deprotected polymers were redissolved in acetone then dried. This was repeated two times to ensure complete removal of all acidic components, after which all polymers were again dried in vacuo.

Homopolymer P1a-1 ${ }^{1} \mathrm{H}$ NMR (300 MHz, $d_{6}$-acetone) $\delta: 5.1-5.4(\mathrm{~m}, 2 \mathrm{H}), 3.9-4.1(\mathrm{~m}, 1 \mathrm{H})$, 3.7-3.9 (m, 1H), 3.0-3.2 (m, 1H), 1.8-2.0 (m, 1H), 1.4-1.8 (m, 3H); ${ }^{13} \mathrm{C}$ NMR $(300 \mathrm{MHz}$, $d_{6}$-acetone) $\delta: 169,166,164,75,73,69,68,67,62,32,23,16$.

Homopolymer P2a-1 ${ }^{1} \mathrm{H} \mathrm{NMR}\left(300 \mathrm{MHz}, d_{6}\right.$-acetone) $\delta: 4.8-5.3(\mathrm{~m}, 2 \mathrm{H}), 3.4-3.5(\mathrm{~m}, 1 \mathrm{H})$, $3.0-3.3(\mathrm{~m}, 1 \mathrm{H}), 1.8-2.1(\mathrm{~m}, 2 \mathrm{H}), 1.3-1.8(\mathrm{~m}, 7 \mathrm{H}) ;{ }^{13} \mathrm{C} \mathrm{NMR}\left(300 \mathrm{MHz}, d_{6}\right.$-acetone) $\delta: 172$, $169,72,69,40,29,28,26,20,16$.

Homopolymer P3a- ${ }^{1} \mathrm{H}$ NMR (300 MHz, $d_{6}$-acetone) $\delta: 5.1-5.4(\mathrm{~m}, 1 \mathrm{H}), 5.0-5.1(\mathrm{~m}, 1 \mathrm{H})$, $2.4-2.8(\mathrm{~m}, 2 \mathrm{H}), 2.2-2.4(\mathrm{~m}, 2 \mathrm{H}), 1.3-1.6(\mathrm{~m}, 3 \mathrm{H}) ;{ }^{13} \mathrm{C} \mathrm{NMR}$ (300 MHz, $d_{6}$-acetone) $\delta: 177$, $176,173,172,171,77,76,71,70,69,62,56,31,28,27,26,18$.

Copolymer CP1a-1 ${ }^{1} \mathrm{H}$ NMR (300 MHz, $\left.\mathrm{CDCl}_{3}\right)$ 8: 5.1-5.3 (m, 7H), 3.7-4.0 (m, 2H), 1.3$1.8(\mathrm{~m}, 18 \mathrm{H}) ;{ }^{13} \mathrm{C}$ NMR $\left(300 \mathrm{MHz}, \mathrm{CDCl}_{3}\right) \delta: 170,167,166,164,74,73,69,68,67,32,22$, $17,16$.

Copolymer CP2a- ${ }^{1} \mathrm{H}$ NMR (300 MHz, $\left.\mathrm{CDCl}_{3}\right)$ : : 4.9-5.3 (m, 16H), 3.4-3.5 (m, 1H), 3.0$3.2(\mathrm{~m}, 1 \mathrm{H}), 1.1-2.1(\mathrm{~m}, 50 \mathrm{H}) ;{ }^{13} \mathrm{C} \mathrm{NMR}\left(300 \mathrm{MHz}, \mathrm{CDCl}_{3}\right) \delta: 170,169,75,69,68,41,40$, $31,23,17$.

Copolymer CP3a- ${ }^{1} \mathrm{H}$ NMR (300 MHz, $\left.\mathrm{CDCl}_{3}\right) \delta: 5.0-5.3(\mathrm{~m}, 8 \mathrm{H}), 2.4-2.6(\mathrm{~m}, 2 \mathrm{H}), 2.2-$ $2.4(\mathrm{~m}, 2 \mathrm{H}), 1.4-1.7(22 \mathrm{H}) ;{ }^{13} \mathrm{C}$ NMR $\left(300 \mathrm{MHz}, \mathrm{CDCl}_{3}\right) \delta: 180,174,173,172,170,169$, $167,72,70,69,68,66,30,29,26,25,16$.

\section{Supplementary Material}

Refer to Web version on PubMed Central for supplementary material.

\section{Acknowledgements}

Financial support has been provided by the National Science Foundation (ChE-0239385) and the National Institute of Health. MW gratefully acknowledges a 3M Untenured Faculty Award, a DuPont Young Professor Award, an Alfred P. Sloan Fellowship, a Camille Dreyfus Teacher Scholar Award, and the GIT Blanchard Assistant Professorship. Initial support of our program in functional lactide research is supported by an award from the Whitaker Foundation to AG and DMC and by the NSF ERC in Tissue Engineering at Georgia Tech and the Georgia Tech/Emory NSF ERC on the Engineering of Living Tissues (EEC-9731643).

\section{References}

1. Albertsson AC, Varma IK. Biomacromolecules 2003;4:1466-1486. [PubMed: 14606869]

2. Drumright RE, Gruber PR, Henton DE. Adv Mater 2000;12:1841-1846.

3. Dechy-Cabaret O, Martin-Vaca B, Bourissou D. Chem Rev 2004;104:6147-6176. [PubMed: 15584698] 
4. Holy CE, Fialkov JA, Davies JE, Shoichet MS. J Biomed Mater Res, Part A 2003;65A:447-453.

5. Jin S, Gonsalves KE. J Mater Sci: Mater Med 1999;10:363-368. [PubMed: 15348137]

6. Simmons TL, Baker GL. Biomacromolecules 2001;2:658-663. [PubMed: 11710018]

7. Kimura Y, Shirotani K, Yamane H, Kitao T. Polymer 1993;34:1741-1748.

8. Leemhuis M, van Steenis JH, van Uxem MJ, van Nostrum CF, Hennink WE. Eur J Org Chem 2003:3344-3349.

9. Trimaille T, Möller M, Gurny R. J Polym Sci, Part A: Polym Chem 2004;42:4379-4391.

10. Kimura Y, Shirotani K, Yamane H, Kitao T. Macromolecules 1988;21:3338-3340.

11. Marcincinova-Benabdillah K, Boustta M, Coudane J, Vert M. Biomacromolecules 2001;2:1279_ 1284. [PubMed: 11777404]

12. Yang, J-y; Yu, J.; Pan, H-z; Gu, Z-w; Cao, W-x; Feng, X-d. Chin J Polym Sci 2001;19:509-516.

13. in't Veld PJA, Dijkstra PJ, Feijen J. Makromol Chem 1992;193:2713-2730.

14. Barrera DA, Zylstra E, Lansbury PT Jr, Langer R. J Am Chem Soc 1993;115:11010-11011.

15. Feng Y, Klee D, Höcker H. Macromol Chem Phys 2002;203:819-824.

16. Yin M, Baker GL. Macromolecules 1999;32:7711-7718.

17. Vogeley NJ, Baker GL, Smith MR III. Polym Prepr (Am Chem Soc, Div Polym Chem) 2005;46:336.

18. Jeong SI, Kim BS, Lee YM, Ihn KJ, Kim SH, Kim YH. Biomacromolecules 2004;5:1303-1309. [PubMed: 15244444]

19. Uhrich KE, Cannizzaro SM, Langer RS, Shakesheff KM. Chem Rev 1999;99:3181-3198. [PubMed: 11749514]

20. Barrera DA, Zylstra E, Lansbury PT, Langer R. Macromolecules 1995;28:425-432.

21. Ouchi T, Fujino A. Makromol Chem 1989;190:1523-1530.

22. Radano CP, Baker GL, Smith MR III. Polym Prepr (Am Chem Soc, Div Polym Chem) 2002;43:727728.

23. Deechongkit S, You SL, Kelly JW. Org Lett 2004;6:497-500. [PubMed: 14961607]

24. Winitz M, Bloch-Frankenthal L, Izumiya N, Birnbaum SM, Baker CG, Greenstein JP. J Am Chem Soc 1956;78:2423-2430.

25. Chamberlain BM, Cheng M, Moore DR, Ovitt TM, Lobkovsky EB, Coates GW. J Am Chem Soc 2001;123:3229-3238. [PubMed: 11457057]

26. O'Keefe BJ, Hillmyer MA, Tolman WB. J Chem Soc, Dalton Trans 2001:2215-2224.

27. US Food and Drug Administration. The List of "Indirect" Additives Used in Food Contact Substances. http://www.cfsan.fda.gov/ dms/opa-indt.html

28. Yang, J-y; Yu, J.; Li, M.; Gu, Z-w; Feng, X-d. Chin J Polym Sci 2002;20:413-417.

29. Johns, DB.; Lenz, RW.; Luecke, A. Ring-Opening Polymerization. 1. Elsevier Applied Science Publisher; London: 1984. p. 461-521.

Biomacromolecules. Author manuscript; available in PMC 2008 September 15. 
<smiles>[R]CC1OC(=O)COC1=O</smiles><smiles>[R]CC1NC(=O)C(C)OC1=O</smiles><smiles>[R]CC1OC(=O)C(C)OC1=O</smiles>

Functional Glycolides $[1,4]$ dioxane-2,5-dione skeleton

Functional Esteramides

6-methyl-morpholine-2,5-dione skeleton

Functional Lactides

6-methyl-1,4-dioxane-2,5-dione skeleton

$\mathrm{R}=$ Functional Appendage at the 3 position

Figure 1.

Functional lactide analogues. 
<smiles>CC1OC(=O)C(COCc2ccccc2)OC1=O</smiles>

Serine Derivative 1<smiles>CCCCCCCCCCCCCCCCCCCOC(=O)OCc1ccccc1</smiles>

Lysine Derivative 2<smiles>CC1OC(=O)C(CCC(=O)OCc2ccccc2)OC1=O</smiles>

\section{Glutamic Acid Derivative 3}

Figure 2.

Functional lactide monomers investigated. 


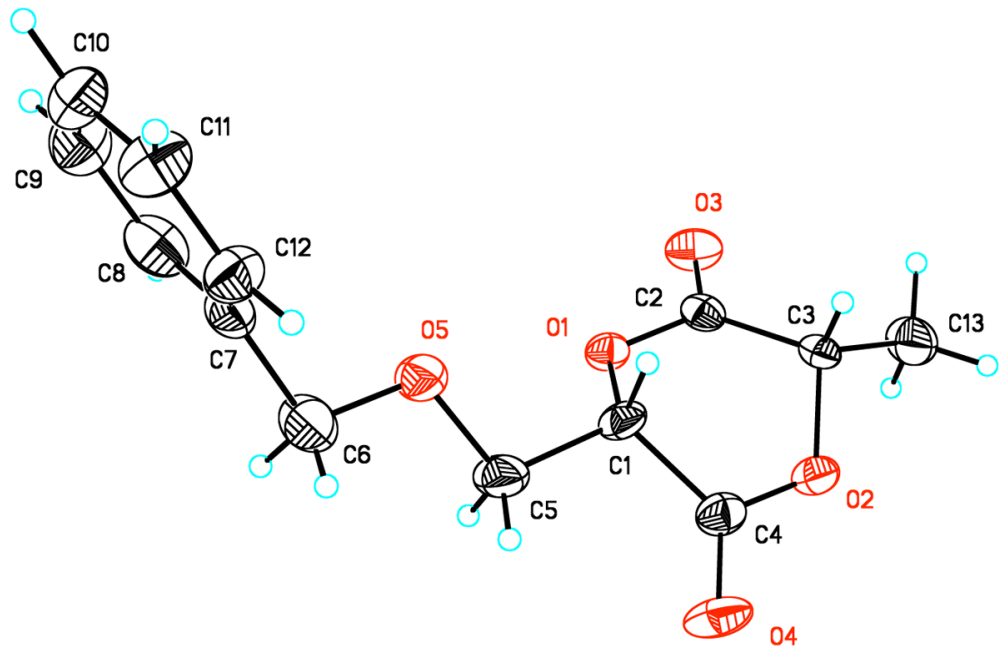

Figure 3.

Crystal structure of monomer $\mathbf{1 .}$ 


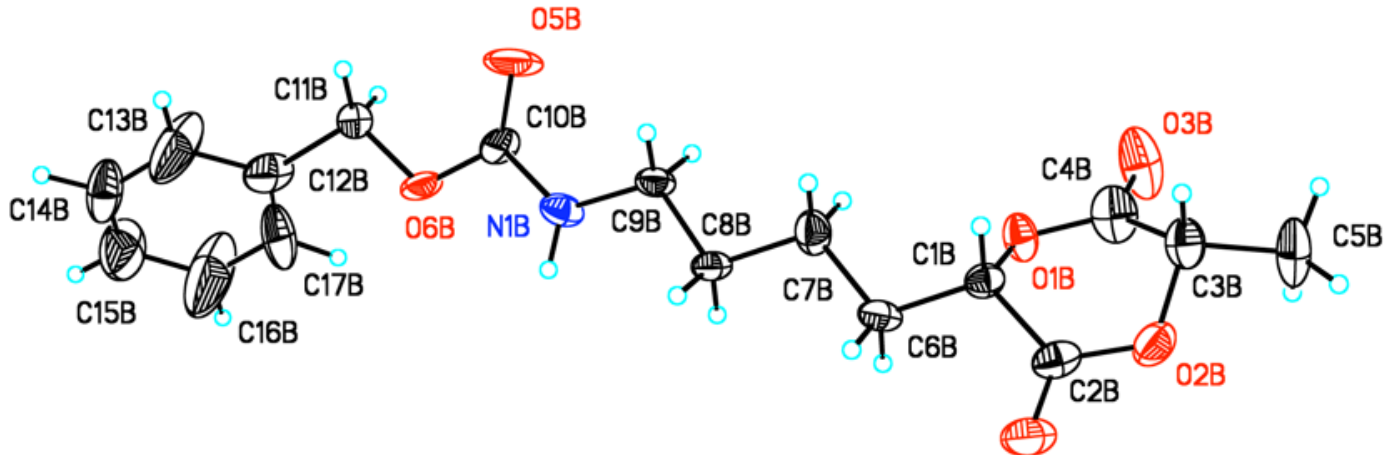

04B

Figure 4.

One unique structure in the asymmetric unit cell of monomer 2. 

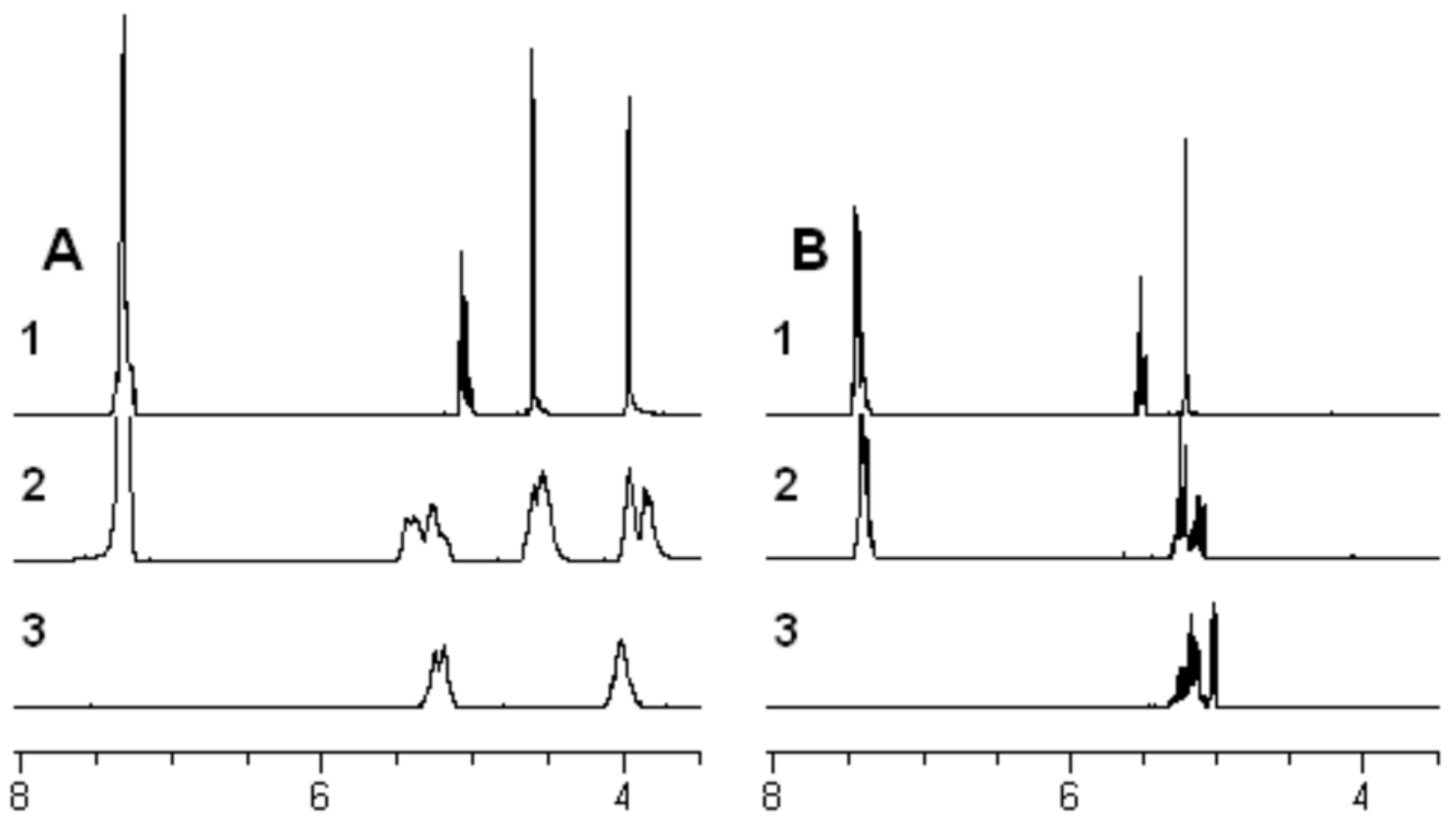

Figure 5.

(A) ${ }^{1} \mathrm{H}$ NMR spectra of serine derivatives in $d_{6}$-acetone: 1) monomer 1 ; 2) homopolymer P1; 3) deprotected homopolymer P1a; (B) ${ }^{1} \mathrm{H}$ NMR spectra of glutamic acid derivatives in $d_{6}$-acetone: 1 ) monomer $\mathbf{3} ; 2$ ) homopolymer $\mathbf{P 3}$; 3 ) deprotected homopolymer P3a. 

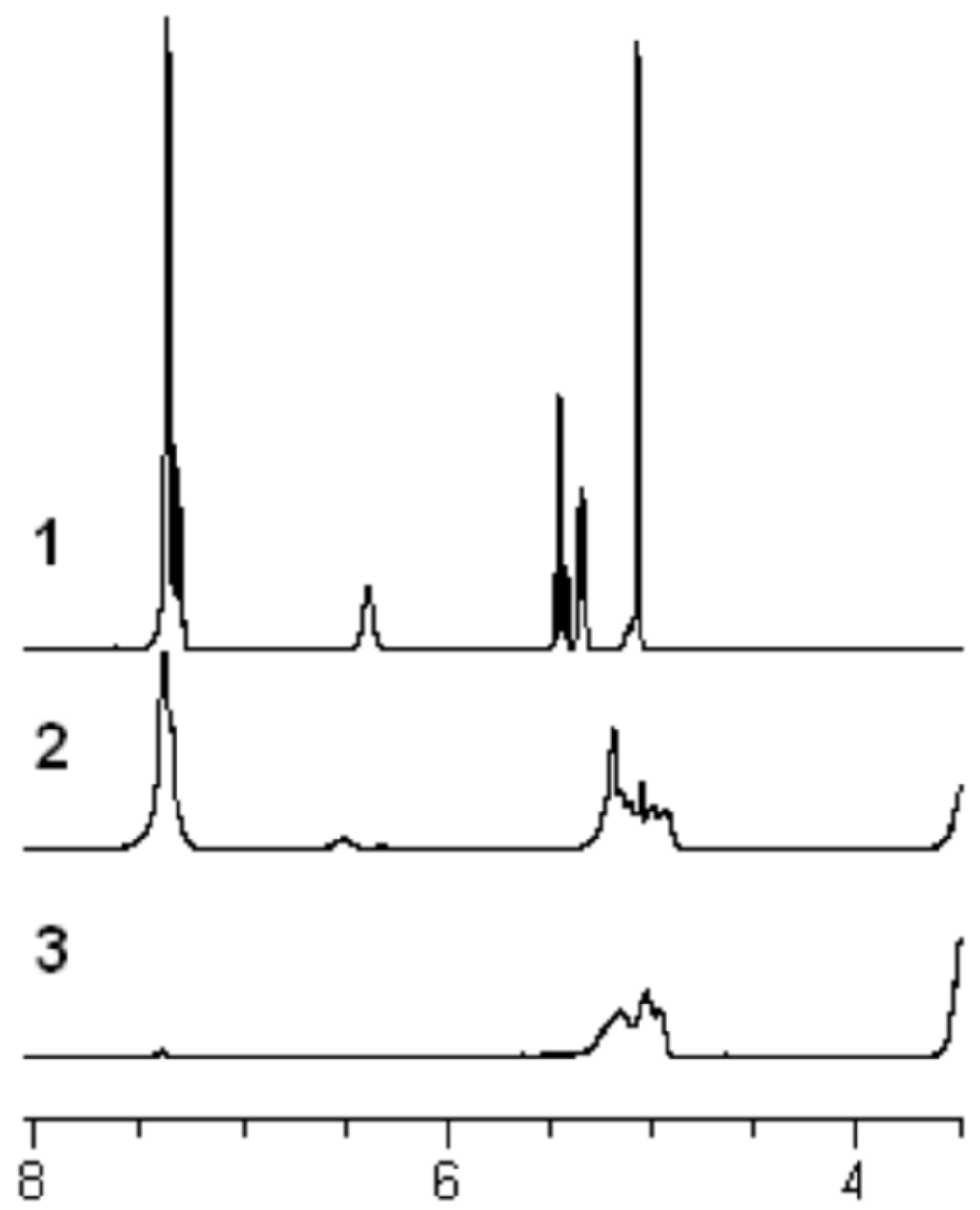

Figure 6.

${ }^{1} \mathrm{H}$ NMR spectra of lysine derivatives in $d_{6}$-acetone: 1$)$ monomer 2 ; 2) homopolymer P2; 3 ) deprotected homopolymer CP2a. 


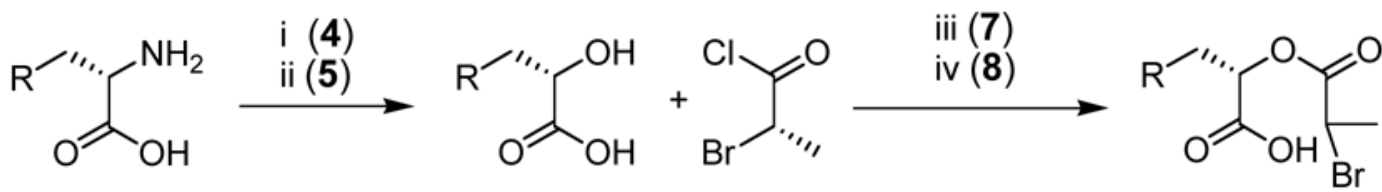

\section{4, 5}<smiles>[Z6]CCCNC(=O)Oc1ccccc1CO[14CH3]</smiles>
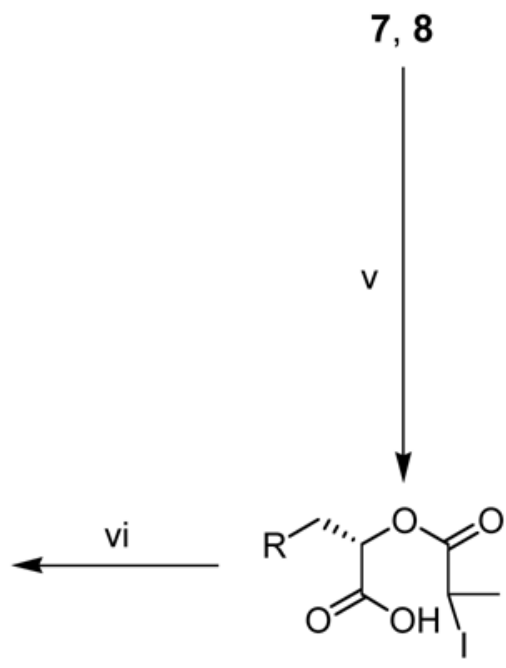

1, 2

10,11

Scheme 1.

Synthesis of cyclic monomers 1 and $\mathbf{2}$ using an acid chloride coupling. Conditions: (i)

$\mathrm{NaNO}_{2}, \mathrm{TFA}_{2} \mathrm{H}_{2} \mathrm{O}, 25^{\circ} \mathrm{C}, 6 \mathrm{~h}$; (ii) $\mathrm{NaNO}_{2}$, aq. $\mathrm{KHSO}_{4}, 0-25^{\circ} \mathrm{C}, 3 \mathrm{~h}$; (iii) $75^{\circ} \mathrm{C}, 6 \mathrm{~h}$; (iv) DIEA, Et $2 \mathrm{O}, 0-40^{\circ} \mathrm{C}, 12 \mathrm{~h}$; (v) KI, acetone, $65^{\circ} \mathrm{C}, 12 \mathrm{~h}$; (vi) DIEA, acetone, $75^{\circ} \mathrm{C}, 10 \mathrm{~h}$. 


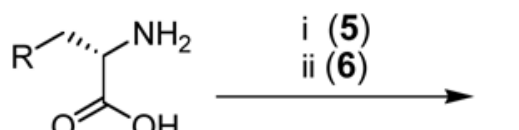<smiles>[R]CC(O)C(=O)O</smiles>

5,6<smiles>[Y]CCCNC(=O)Oc1ccccc1</smiles>

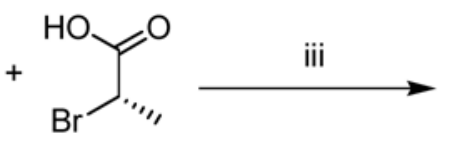<smiles>[R]C[C@H](OC(=O)[C@H](C)Br)C(=O)O</smiles><smiles>[R]C[C@H]1OC(=O)[C@@H](C)OC1=O</smiles>

2, 3 iv

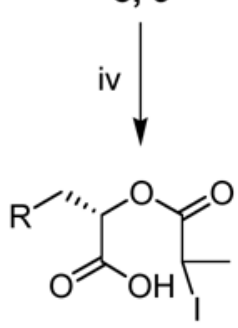

11,12

Scheme 2.

Synthesis of cyclic monomers 2 and 3. Conditions: (i) $\mathrm{NaNO}_{2}$, aq. $\mathrm{KHSO}_{4}, 0-25{ }^{\circ} \mathrm{C}, 3 \mathrm{~h}$; (ii) $\mathrm{NaNO}_{2}, 1: 1 \mathrm{AcOH} / \mathrm{H}_{2} \mathrm{O}$ (v/v), 0-25 ${ }^{\circ} \mathrm{C}, 3 \mathrm{~h}$; (iii) DCC, $\mathrm{HOBt}, \mathrm{CH}_{2} \mathrm{Cl}_{2}, 25^{\circ} \mathrm{C}, 12 \mathrm{~h}$; (iv) KI, acetone, $65^{\circ} \mathrm{C}, 12 \mathrm{~h}$; (v) DIEA, acetone, $75^{\circ} \mathrm{C}, 10 \mathrm{~h}$. 


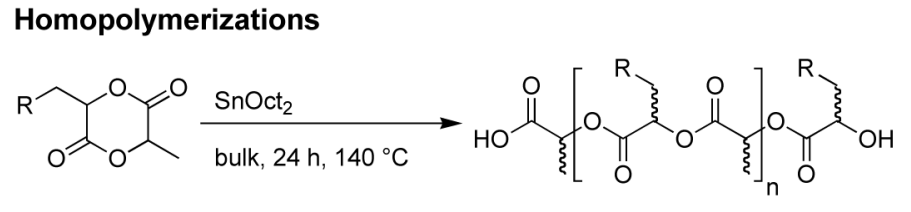

$1,2,3$

\section{Copolymerizations}

P1, P2, P3

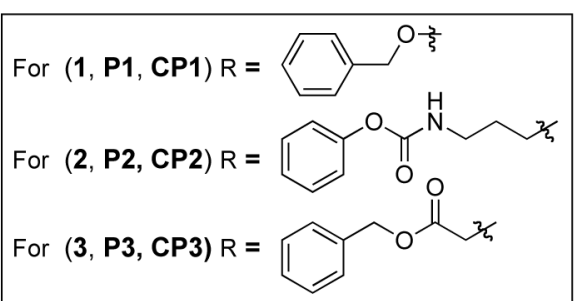

1,2 , or 3

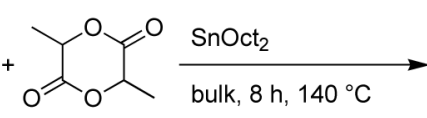

$25 \mathrm{~mol} \% \quad$ : $75 \mathrm{~mol} \%$<smiles>[R]C[C@H](OC(=O)[C@H](C)OC(=O)[C@H](C)OC(=O)[C@H](C)O)C(=O)O[C@@H](C)C(=O)O[C@@H](C)[C@@H](C)C(=O)O</smiles>

CP1, CP2, CP3

Scheme 3.

Homo- and co-polymerizations of $\mathbf{1 , 2}$, and $\mathbf{3}$. 


\section{A Benzyl Ether and Benzyl Ester Protected Polymers}

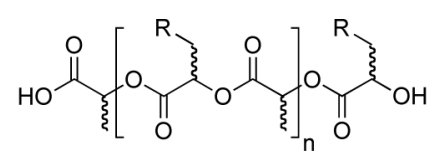

P1, P3

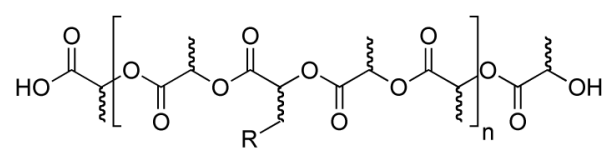

CP1, CP3

\section{$\mathrm{Pd}(\mathrm{OH})_{2} / \mathrm{C}, 50 \mathrm{PSI} \mathrm{H}$}

EtOAc, $25^{\circ} \mathrm{C}, 4 \mathrm{~h}$<smiles>[R]C[C@H](O)C(=O)O[C@H](C)[C@@H](C)OC(=O)[C@H](C[R])C(=O)O[C@@H](C)[C@@H](C)C(=O)O</smiles>

P1a, P3a

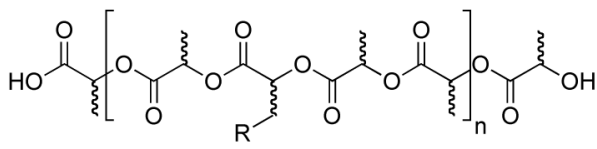
CP1a, CP3a

B Benzyl Carbamate Protected Polymers

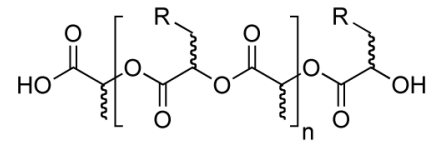

P2

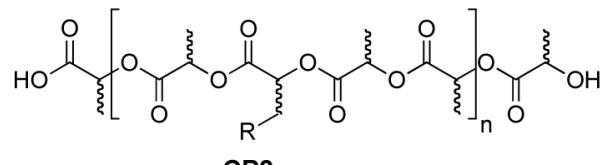

CP2
$\mathrm{HBr} / \mathrm{ACOH}$ $25^{\circ} \mathrm{C}, 2 \mathrm{~h}$

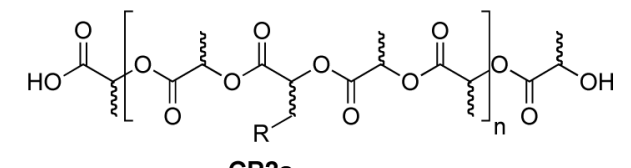<smiles>[Y]CCCNC[Y]</smiles>

Scheme 4.

Deprotection strategies for protected polymers: (A) Hydrogenolysis of benzyl ethers and esters; (B) Acidolysis of benzyl carbamates. 
Table 1

Homopolymer characterization data.

\begin{tabular}{ccccc}
\hline Polymer & $\boldsymbol{M}_{\mathbf{n}}\left(\mathbf{1 0}^{-\mathbf{3}}\right)^{\boldsymbol{a}}$ & PDI & $\boldsymbol{T}_{\boldsymbol{g}}\left({ }^{\circ} \mathbf{C}\right)$ & Yield (\%) \\
\hline $\mathbf{P 1}^{b}$ & 21 & 1.5 & 18 & 79 \\
$\mathbf{P 2}$ & 8 & 1.4 & 20 & 60 \\
$\mathbf{P 3}$ & 3 & 1.4 & 10 & 29 \\
\hline
\end{tabular}

${ }^{a} \mathrm{GPC}$ in $\mathrm{CH}_{2} \mathrm{Cl}_{2}$ with poly(styrene) standards;

$b_{\text {identical for either diastereomer. }}$ 


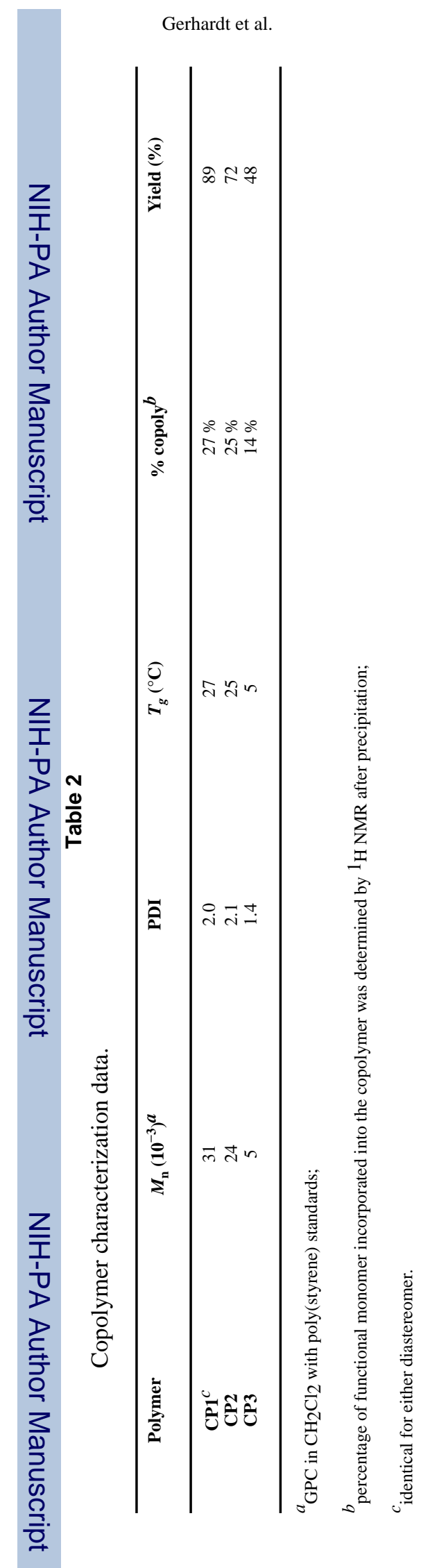

Biomacromolecules. Author manuscript; available in PMC 2008 September 15. 